\title{
Effect of Microencapsulation on the Development of Antioxidant Activity and Viability of Lactobacillus acidophilus LA5 in Whey Drink During Fermentation
}

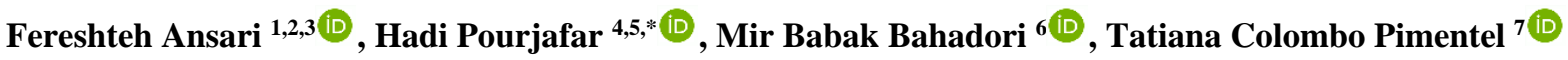 \\ 1 Research Center for Evidence-Based Medicine, Health Management and Safety Promotion Research Institute, Tabriz \\ University of Medical Sciences, Tabriz, Iran; fereshtehansari66@gmail.com (F.A); \\ 2 Razi Vaccine and Serum Research Institute, Agricultural Research, Education and Extension Organization (AREEO), \\ Tehran, Iran \\ 3 Iranian EBM Centre: A Joanna Briggs Institute Affiliated Group, Iran \\ 4 Department of Food Sciences and nutrition, Maragheh University of Medical Sciences, Maragheh, Iran; \\ pourjafarhadi59@gmail.com (H.P); \\ 5 Alborz University of Medical Sciences, Dietary supplements and Probiotic Research Center, Karaj, Iran \\ 6 Medicinal Plants Research Center, Maragheh University of Medical Sciences, Maragheh, Iran; mb.bahadori@gmail.com \\ (M.B.B); \\ 7 Federal Institute of Paraná, Paranavaí, Paraná, Brazil; tatiana.pimentel@ifpr.edu.br (T.C.P); \\ * Correspondence: pourjafarhadi59@gmail.com;
}

Scopus Author ID 54881252100

Received: 4.08.2020; Revised: 9.09.2020; Accepted: 12.09.2020; Published: 16.09.2020

\begin{abstract}
Encapsulation could be used for increasing of probiotic's viability and maintaining of product's quality during storage. The encapsulation process was performed using alginate-resistant starch and Eudragit S100 nanoparticles and by the extrusion technique. In whey drink, the viability of encapsulated L. acidophilus was upper in comparison to the free probiotic bacteria $(\mathrm{P}=0.001)$. The viability of bacteria reduced significantly during the study ( $\mathrm{P}<0.001$ in both groups), and encapsulated bacteria were more stable during the storage time than free forms $(\mathrm{P}=0.046)$. In gastrointestinal conditions, the viability of bacteria was reduced significantly during the 120 min study period in both groups $(\mathrm{P}<0.001$ for free form and $\mathrm{P}=0.001$ for microencapsulated bacteria). Encapsulated bacteria were more stable than free form $(\mathrm{P}<0.001)$. Free bacteria containing whey products exhibited an increasing antioxidant activity from beginning day to the fifth week (0.1-2.6 mmol Trolox equivalents/ $\mathrm{mL}$ sample). Whey drinks with encapsulated bacteria showed similar antiradical properties for the first time, but their increasing activity rate within 35 days was lower than free form samples (0.1-0.9 mmol Trolox equivalents/mL sample). This technique of encapsulation can prevent bacteria from reducing their survivability. Whey products prepared using L. acidophilus (especially in free form) could be considered as a potent antioxidant functional drink.
\end{abstract}

Keywords: microencapsulation; probiotic; Lactobacillus acidophilus; whey; microbial survival.

(C) 2020 by the authors. This article is an open-access article distributed under the terms and conditions of the Creative Commons Attribution (CC BY) license (https://creativecommons.org/licenses/by/4.0/).

\section{Introduction}

Probiotic microorganisms (such as Lactobacilli and Bifidobacteria) are food ingredients that, when consumed (as in a food or a dietary supplement), maintain or restores useful bacteria to the gastrointestinal (GI) tract [1,2]. These microorganisms improve the health status of the consumer via several identified and unidentified mechanisms. They have positive effects on a wide range of infectious and hypersensitivity disorders, and it is shown that they can increase human metabolism and relieve chronic intestinal inflammatory and functional problems [3-5]. 
Foods containing probiotic bacteria are categorized as functional foods. A probiotic functional food to have helpful effects on health should contain at least $10^{7} \mathrm{cfu} / \mathrm{g}$ probiotic bacteria and consumed at levels higher than $100 \mathrm{~g} /$ day $[6,7]$. Dairy products have long been used as probiotic carriers; however, there are some issues regarding the efficacy of dairy products as probiotic functional foods [8]. One of them is the viability of probiotics during the storage of dairy products and after that through GI tube to their site of action. Cold stress, exposure to acid and bile, and osmotic and oxidative stress may reduce the number of probiotic bacteria to a level below the effective threshold $[9,10]$.

Microencapsulation is a well-proven technique to improve the survival of probiotics in both product storage and GI condition $[10,11]$. This method can help the continued existence of probiotics during various manufacturing procedures and GI undesirable circumstances [7, 12-17].

Calcium alginate (an anionic liner heteropolysaccharide) is a material that has been successfully used for the encapsulation of lactic acid bacteria (LAB). The uncomplicated application, safety, and cost-effectiveness made it one of the most broadly used materials for microencapsulation [7, 18, 19]. However, it is sensitive to chelating agents and acidic conditions below pH 2, and it has limited its application. Resistant starch (RS) as a cationic polysaccharide is a material which improves the strength of alginate beads and subsequently enhances the viability of probiotic microorganisms in harsh situations. RS can be used as a coat to support micro-coverage over other negative-charge micro-covers [14, 20].

Eudragit (Eu) S100 (an anionic copolymer of methacrylic acid and methyl methacrylate that it is soluble in $\mathrm{pH} \mathrm{7,} \mathrm{but} \mathrm{non-soluble} \mathrm{in} \mathrm{acidic} \mathrm{conditions} \mathrm{and} \mathrm{water)} \mathrm{has} \mathrm{been} \mathrm{employed}$ for micro/nanoencapsulation and is able to also improve the efficacy of encapsulation by targeted release in the colon $(\mathrm{pH} 7)$ and inhibition of rapid dissolution of beads through the gastric cavity and the upper small intestine [21,22]. Eu polymers are categorized as food-grade and non-toxic polymers and can be used as the secondary coat (after first coating of RS over the alginate beads) for strengthening the microencapsulation [23, 24]. It can also ensure the targeting release of probiotic microorganisms into the main functional place for probiotics consumers (i.e., colon) [22, 25-27]. Eu nanoparticles found a thin nano-size layer surrounding the beads. This extremely slight thin layer increases the strength of beads without expanding the size of them. Smaller beads may decrease the oral sense of beads in a foodstuff carrier and also reduce costly Eu powder [27-29].

Whey is a by-product of cheese, which has been shown to have beneficial effects on human ailments. The bioconversion of this material is a profitable process from the viewpoint of human nutrition and therapeutic purposes, as well as the economic and environmental aspects [30]. Adding probiotic bacteria to the whey may increase its health effects and improve its quality.

In this study, we attempted an examination of whey drink containing probiotics bacteria (Lactobacillus acidophilus LA5). Free and microencapsulated bacteria are compared for survivability in whey drink production and subsequently in simulated GI situation.

\section{Materials and Methods}

\subsection{Preparation of Lactobacillus acidophilus LA5.}

Probiotic bacterium culture of L. acidophilus (PTCC 4356, Iranian Research Organization for Science and Technology) were inoculated into MRS-broth and incubated at 
$37 \pm 2{ }^{\circ} \mathrm{C}$ for $18 \mathrm{~h}$ in the anaerobic situation. Subsequently, the bacterium was gathered by centrifugation (Centrion Centrifuge, Model 2010, West Sussex, BNI8OHY, UK) at 5,000 rpm for 15 min., and then, it was washed two times (by sterilized distilled water) before applying in the encapsulation process $[14,20]$.

\subsection{Preparation of Eudragit S100 nanoparticles.}

Eu S100 powder was achieved from Evonik Pharma Polymers (Evonik, D-64275, Darmstadt, Germany). To formulate the Eu S100 nanoparticles, we applied modified Supercritical Antisolvent Technique (SAS) progression (as a modified SAS procedure; we used homogenization power as a replacement for applying high pressure) in accordance with the technique that previously described by Ansari et al. (2017). In this technique, the option of acetone was used as a solvent for Eu powder. In this method, $4 \mathrm{mg} \mathrm{mL}-1$ of Eu solution was applied in distilled water slowly as a supercritical fluid that had been held under homogenization compression (Wisetise, DAIHAN Scientific Co., Ltd, Korea) at 26,000 rpm at $35{ }^{\circ} \mathrm{C}$ for $10 \mathrm{~min}$. Also, distilled water as a surfactant included $15 \mathrm{mg}$ L-1 Tween 80 (Merk, Hohenbrunn, Germany). Finally, the acetone solvent was evaporated. The particle size of the Eu and PDI (polydispersibility/polydispersivity index) was assessed via the Laser Particle Size Analyzer apparatus (Brookhaven Instruments Corporation, USA) [22, 25, 31, 32].

\subsection{Encapsulation and the double coating of the probiotic bacterium.}

Extrusion way with sodium alginate and calcium chloride was carried out for the encapsulation method described former by Mirzaei et al. (2011). The first coating of beads with resistant starch was carried out by Mirzaei et al. (2011) and Homayouni et al. (2008), and the next coating with Eudragit S100 nanoparticles was completed by Badhana et al. (2013), Hu et al. (2012) and Yoo et al. (2011) methods respectively. A 4\% Na-alginate blend in distilled water containing $0.1 \%$ culture was prepared. Then, the mix of cell suspension $+\mathrm{Na}$-alginate was injected into a $0.1 \mathrm{M} \mathrm{CaCl}_{2}$ solution through an insulin syringe. For the first coating, the beads were submerged in $100 \mathrm{ml}$ of $4 \%$ Hi-maize resistant starch (Merck, Darmstadt, Germany) for 60 min on a magnetic stirrer (IKA Labortechnik, Model 79219 Staufen, KG, Germany). Next, the resistant starch single coated beads were collected and washed through distilled water. In the ending step, for the second coating, the beads were immersed in $100 \mathrm{ml}$ Eu S100 nanoparticles solution (4 mg $100 \mathrm{ml}^{-1}$ ) and held for $4 \mathrm{~h}$ on the shaker [21, 22, 25, 31, 33-35]. Finally, these double-coated beads were collected and rinsed carefully with distilled water and utilized on the same day.

\subsection{Whey drink preparation.}

Pooled cow milk was heated to $85^{\circ} \mathrm{C}$; the citric acid $(2 \%)$ solution was then added at the rate of $2 \mathrm{~g} / \mathrm{kg}$ of milk. Complete coagulation was affected within one minute, and the whey filtered cloth was used as the base material for cheese. The whey obtained was adjusted to $\mathrm{pH}$ 5.5 using $10 \% \mathrm{NaHCO}_{3}$ solution and was heated at $100^{\circ} \mathrm{C}$ for 10 min with $0.4 \% \mathrm{CaCl}_{2}$ and kept undisturbed overnight at room temperature and filtered to obtain deproteinized whey [14, 30]. 


\subsection{Antioxidant activity measurements.}

Radical scavenging activity was evaluated via a decolorization technique as described earlier by $\mathrm{Re}$ et al. (1999). In this assay, 2, 2'-azino-bis (3-ethylbenzothiazoline-6-sulfonic acid) (ABTS) is oxidized to produce the colored $\mathrm{ABTS}^{{ }^{++}}$radical, which is again reduced to a colorless complex if the sample of interest comprises hydrogen-donating antioxidants. In brief, one $\mathrm{mL}$ of diluted ABTS radical solution $(7 \mathrm{mM})$ in PBS was added to $10 \mu \mathrm{L}$ whey sample and also Trolox (6-hydroxy-2,5,7,8-tetramethychroman-2-carboxylic acid in PBS) standards (0-15 $\mu \mathrm{M})$. The mixture was shaken for $1 \mathrm{~min}\left(\right.$ at $30^{\circ} \mathrm{C}$ ), and its absorbance was measured at $734 \mathrm{~nm}$ throughout 6 min of reaction time. The percentage inhibition of ABTS radicals was determined according to the concentration of whey samples and Trolox as below:

Inhibition $\%=[($ A 734 blank - A734 sample $) /$ A734 blank $] \times 100 \%$

Results expressed as equivalents of Trolox (mmol trolox equivalents/mL sample).

\subsection{Survival of probiotic bacteria during storage in whey drink.}

Bacterial analysis of numeral was determined in accordance with the way explained previously by Ansari et al. (2017) and Shah (2000) after the production of whey drink for the duration of 42 days with one week as interval time. The samples of whey drink $(10 \mathrm{ml})$ were diluted into $90 \mathrm{ml}$ distilled water, and then $1 \mathrm{ml}$ aliquot dilutions were distributed to each plate of the MRS-Salicin-agar [13, 31, 36, 37]. All Counting plates of L. acidophilus LA5 were incubated at $37{ }^{\circ} \mathrm{C}$ for $48-72 \mathrm{~h}$ in the anaerobic situation. To enumerate the encapsulated bacteria inside whey drink, the captured bacteria were freed from beads illustrated previously by Ansari et al. (2017). Ten $\mathrm{ml}$ of whey drink were blended with $90 \mathrm{~mL}$ of phosphate buffer $\left(0.1 \mathrm{~mol} \mathrm{~L}^{-1}, \mathrm{pH}\right.$ 7.0) followed by $60 \mathrm{~min}$ shaking in a bag blender (netech-laboratory, Bag Tech $\left.{ }^{\circledR}\right)$. Then, $1 \mathrm{ml}$ of aliquot dilutions were distributed to each plate of the MRS-Salicin-agar (See Fig. 1).

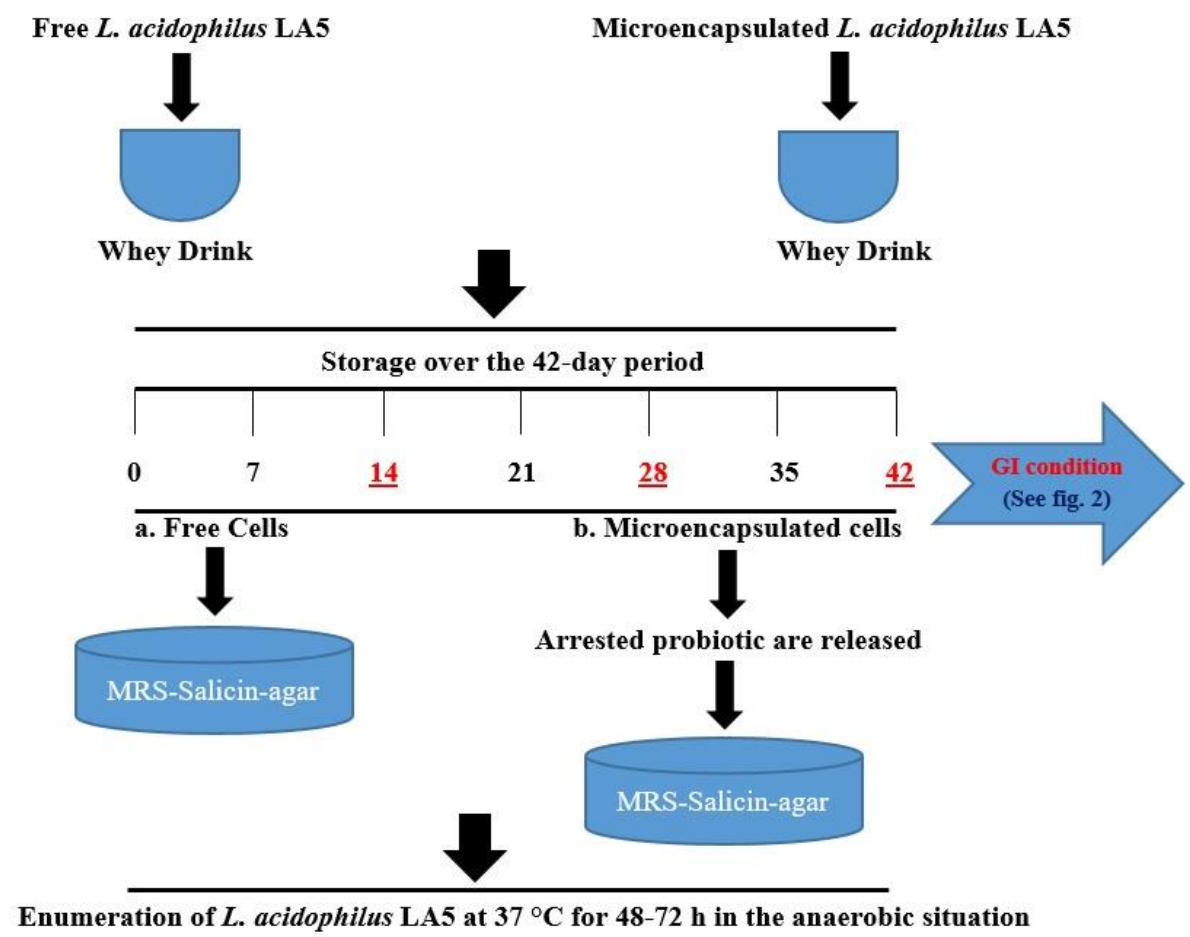

Figure 1. Survey of the viability of free and microencapsulated bacteria into whey drink following the production of probiotic whey at the time at 0 and during the 42 days period with one-week interval time (the storage temperature was $5^{\circ} \mathrm{C}$ ). 
2.7. Survival of probiotic bacteria throughout GI simulation condition (in vitro).

The survivability of free and microencapsulated bacteria in GI simulation environment was examined after 30, 60, 90- and 120-minutes incubation. The beads ( $1 \mathrm{~g})$ were singly put in a GI condition described earlier by Ansari et al. (2017). Finally, samples were diluted into sterilized peptone water, and $1 \mathrm{ml}$ aliquot dilutions were dispensed to plates of the MRSSalicin-agar. All Counting plates were incubated at $37 \pm 2{ }^{\circ} \mathrm{C}$ for $48-72 \mathrm{~h}$ in anaerobic condition. To enumerate the encapsulated bacteria, the captured bacteria were released as beads [14, 31, 38, 39] (See Fig. 2).

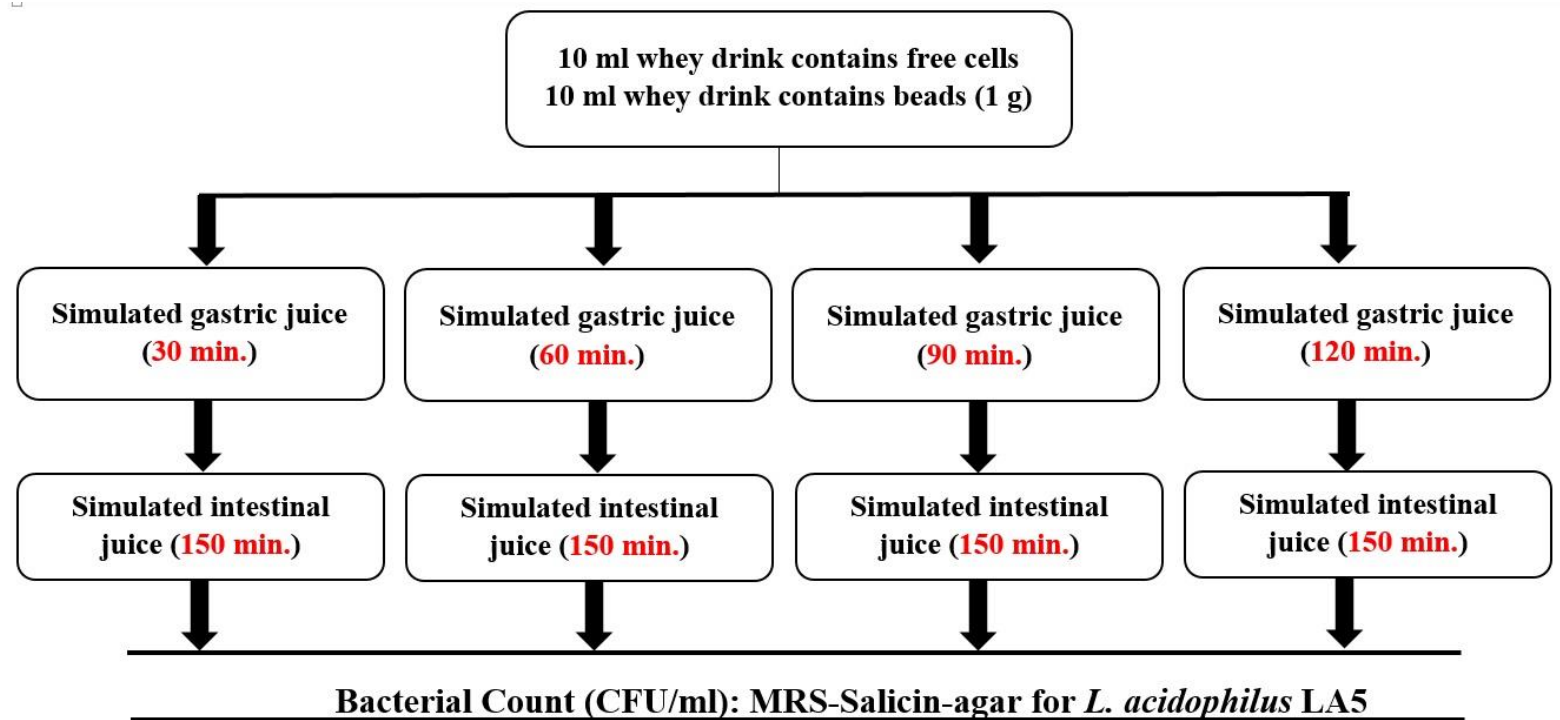

Figure 2. Survey of the viability of free and microencapsulated bacteria under simulated gastrointestinal circumstances in 14, 28, and 42 days following inoculation of bacteria (in two types; free and encapsulated with double coating) in whey drink.

\subsection{Statistical analysis.}

The survivability of bacteria in whey samples containing free and microencapsulated probiotic bacterium was compared by Paired-Samples T-test. ANOVA test was also carried out to test the difference in the viability of bacteria during a 42-day storage period. In a survey of the viability rate of probiotic bacteria throughout GI simulation condition, the difference between free and microencapsulated bacteria was assessed using Paired-Samples T-test and the survivability during 120 minutes within each experimental group was tested by ANOVA.

In the case of antioxidant activity, differences between each group in each day were compared using Independent Samples T-test (for days 7, 14, 21, 35, and 42) and Mann Whitney U Test (for day 0, which was not normally distributed). Measurements of each of the free and encapsulated groups during 42 days study period were compared by the Freidman test.

\section{Results and Discussion}

\subsection{Production of Eudragit S100 nanoparticles.}

In this research, $\sim 100 \mathrm{~nm}$-sized encapsulated particles were prepared via homogenization of Eu S100 powder (26000 rpm, $10 \mathrm{~min}$ ). Hu et al. (2012) employed Eu S100 powder and acetone solvent with the SAS technique to create nanoparticles of Eudragit. They achieved homogeneous nanoparticles with satisfactory size $(147 \mathrm{~nm})$. The study performed at $15 \mathrm{MPa}$ pressure and $35^{\circ} \mathrm{C}$. In our study, we used the homogenization process to crash particles 
instead of rising pressure, and the size of achieved nanoparticles by our technique was analogous to $\mathrm{Hu}$ et al. study. Following preparation of the Eu S100 by modified SAS processing, the PDI and particle size of Eu S100 particles was $100 \mathrm{~nm}$ and 0.410, respectively.

\subsection{Survival of Lactobacillus acidophilus LA5 during storage into whey drink.}

Bacterial count in whey drink containing free and encapsulated bacteria is demonstrated in Figure 3. The bacterial count was repeated twice for each sample, and the mean and standard deviation of these repetitions are demonstrated. The survivability of the microencapsulated form of bacteria was higher in comparison to the free form of bacteria $(\mathrm{P}=0.001)$. The survivability of bacteria reduced significantly during the study ( $\mathrm{P}<0.001$ in both groups), and microencapsulated bacteria were more stable during the storage time than free forms $(\mathrm{P}=0.046)$.

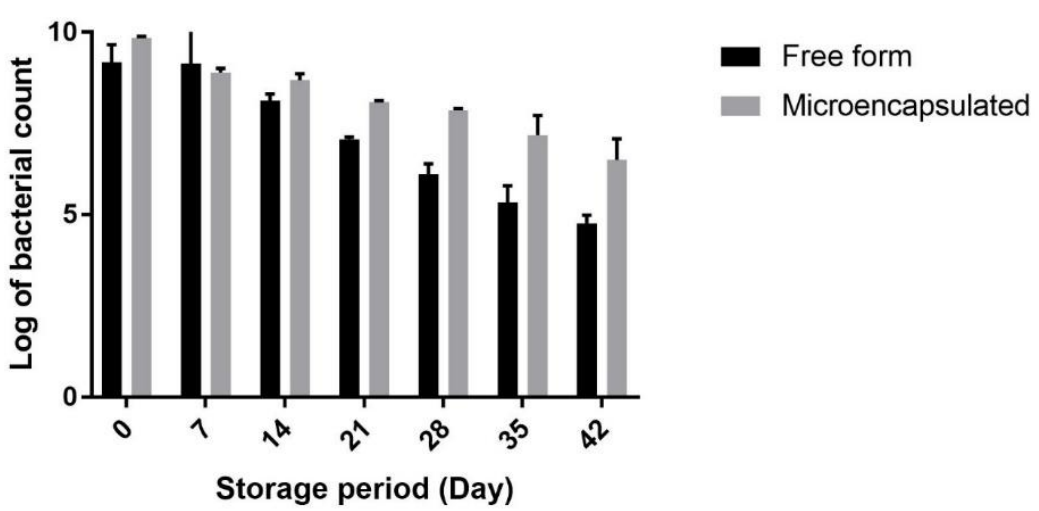

Figure 3. The viability of free and encapsulated Lactobacillus acidophilus LA5 (Log of bacterial count) into whey drink during 42 days with one week as interval time.

Calcium alginate creates a tender membrane between probiotic bacteria and harsh environmental circumstances; so, we used resistant starch as an outer layer to improve the strength of beads. Resistant starch itself is roughly vulnerable to deterioration via acids in low $\mathrm{pH}$ situations and also in the presence of bile and pancreatic enzymes, so we coated the second layer of anionic Eu S100 around the cationic starch layer. This second nano-layer is slight and improves the resistance of beads in harsh GI situation without significant change in the size of beads. Beads with this second nano-layer release in particular $\mathrm{pH}$ states and in target place as colon [40-42]. The results of this study show that Eu S100 nanoparticles on the resistant starch layer can appropriately guard probiotic bacteria and maintain the acceptable numeral of probiotics in whey drink throughout the storage era.

\subsection{Survival of probiotic bacteria throughout GI simulation condition.}

Even though the survivability of probiotics is most important through the shelf-life of a product, the probiotic viability under simulated passage through the GI lumen is imperious since the probiotic bacteria must be able to grow and colonize the GI lumen to confer health advantages to the host. Former investigations have indicated that probiotic microorganisms have a tendency to be inactivated throughout their passage through the GI tract and consequently do not reach the colon undamaged [43]. Henceforth, we investigated the effect of microencapsulation on cell viability after storing into whey drink and after subjected to simulated GI situations. The results of the bacterial count in the simulated GI condition are shown in Figure 4. The bacterial count was repeated twice for each sample, and the mean and 
standard deviation of these repetitions are presented. The viability of bacteria was reduced significantly during the 120-minute study period in both groups $(\mathrm{P}<0.001$ for free form and $\mathrm{P}=0.001$ for microencapsulated bacteria). Microencapsulated bacteria were more stable than free form $(\mathrm{P}<0.001)$ (See Fig. 4).

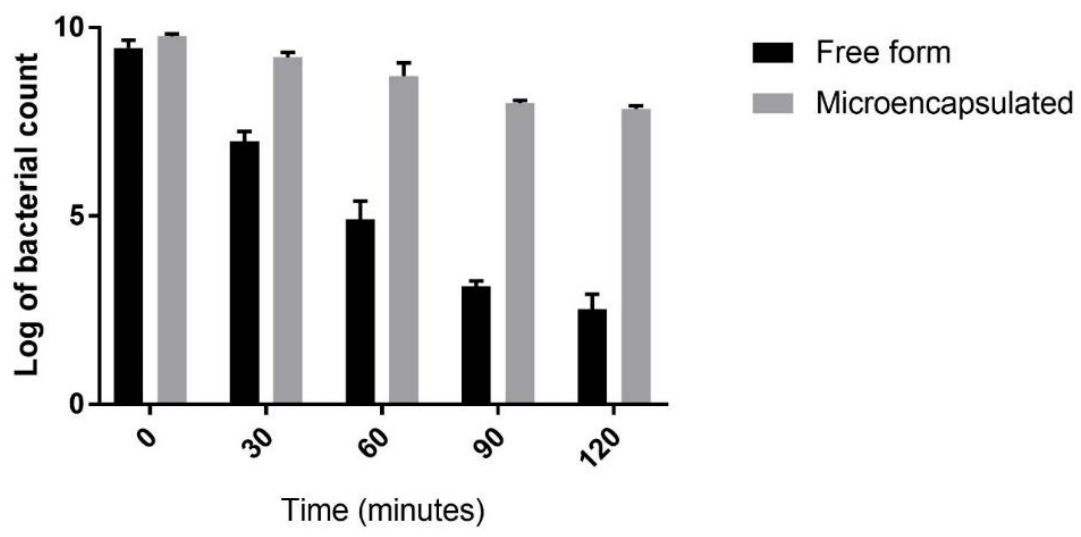

Figure 4. The viability of free and encapsulated Lactobacillus acidophilus LA5 (Log of bacterial count) into simulated gastrointestinal conditions after 30, 60, 90, and 120 minutes incubation.

\subsection{Antioxidant activity.}

The antioxidant activity of cheese whey was evaluated using ABTS method during fermentation by LA5. For this, whey samples containing free or encapsulated forms of bacteria were investigated within six weeks (Table 1). Free bacteria containing whey products exhibited an increasing antioxidant activity from beginning day to the fifth week (0.1-2.6 mmol Trolox equivalents/mL sample). Whey drinks with encapsulated bacteria showed similar antiradical properties for the first time, but their increasing activity rate within 35 days (5 weeks) was lower than free form samples (0.1-0.9 mmol Trolox equivalents/mL sample). As could be seen from Table 1, both types of products showed a decreased activity in the sixth week. It is clear that Lactobacillus acidophilus is involved in many chemical changes during the fermentation process of produced whey drinks. It seems that fermentation products are responsible for the observed antioxidant activities. Whey ingredients are available easily to LA5 when it is free in the media, and so bacteria could perform different reactions to produce many new compounds with radical scavenging activity. On the other hand, when the bacteria are capsulated, it has fewer access to ingredients, and this leads to fewer antioxidant products.

Table 1. The antioxidant activity (nmol L-1 $\left.\mathrm{moml} \mathrm{L}^{-1}\right)$ of Lactobacillus acidophilus LA5 was measured during the fermentation of whey drink during a 42-day period.

\begin{tabular}{l|l|l|l|l|l|l|l|l} 
& Probiotic bacteria & Time (day) & & & & & & \\
\hline & & 0 & 7 & 14 & 21 & 28 & 35 & 42 \\
\hline Antioxidant & Free form & 0.1 & 0.7 & 0.9 & 1.3 & 1.9 & 2.3 & 1.9 \\
activity (nmol L $^{-1}$ & & 0.2 & 0.9 & 1.2 & 1.5 & 2.0 & 2.5 & 1.8 \\
moml L $^{-1}$ ) & & 0.1 & 0.8 & 1.0 & 1.8 & 2.2 & 2.6 & 1.5 \\
\hline & Encapsulated form & 0.1 & 0.5 & 0.6 & 0.8 & 0.9 & 1.0 & 0.8 \\
& & 0.1 & 0.4 & 0.6 & 0.9 & 0.9 & 0.9 & 0.9 \\
& & 0.0 & 0.5 & 0.7 & 0.7 & 0.8 & 0.9 & 0.9
\end{tabular}

\section{Conclusions}

In this investigation, we applied resistant starch and Eu S100 nanoparticles for coating encapsulated L. acidophilus LA5 in whey drink and assessed the viability of contained the probiotic bacterium throughout a 42 days investigation period. The results of this study propose that microencapsulation of $L$. acidophilus LA5 with calcium-alginate and then double layer 
coating of these beads through resistant starch and Eu S100 nanoparticles can increase the viability of this probiotic bacterium in whey drink in addition to the human GI tract. This technique of encapsulation can also prevent bacteria from producing acids and metabolites that contribute to damage the probiotic bacteria and reduce their survivability. The second coating layer-Eu S100 nanoparticles not only protect beads in the acidic environment but also can cause beads to release in the colon region, which is the target location for the best function of probiotic microorganisms. Also, it could be concluded that whey product prepared using $L$. acidophilus LA5 (especially in free form) could be considered as a potent antioxidant functional drink.

\section{Funding}

This research received no external funding.

\section{Acknowledgments}

The authors would like to acknowledge the financial support of Maragheh University of Medical Sciences for this research under grant number 64/1D/619.

\section{Conflicts of Interest}

The authors declare no conflict of interest.

\section{References}

1. Johnson, C.R.; Fischer P.R. Feeding the Microbiota: Complementary Foods Enhance Recovery in Malnourished Children by Modulating the Gut Microbiota. Infect Dis Alert 2020, 39.

2. FAO/WHO. Guidelines for the evaluation of probiotics in food. London: World Health Organization, ON, Canada: Food and Agriculture Organization 2002.

3. López-Moreno, A.; Aguilera, M. Probiotics Dietary Supplementation for Modulating Endocrine and Fertility Microbiota Dysbiosis. Nutrients 2020, 12, https://doi.org/10.3390/nu12030757.

4. Yang, X.; Liu, Y.; Guo, X.; Bai, Q.; Zhu, X.; Ren, H.; Chen, Q.; Yue, T.; Long. F. Antiallergic activity of Lactobacillus plantarum against peanut allergy in a Balb/c mouse model. Food Agri Immunol 2019, 30, 762773, https://doi.org/10.1080/09540105.2019.1631261.

5. Hill, C.; Guarner, F.; Reid, G.; Gibson, G.R.; Merenstein, D.J.; Pot, B.; Morelli, L.; Canani, R.B.; Flint, H.J.; Salminen, S. Expert consensus document: The International Scientific Association for Probiotics and Prebiotics consensus statement on the scope and appropriate use of the term probiotic. Nature Rev Gastroenterol Hepatol 2014, 11, 506-514, https://doi.org/10.1038/nrgastro.2014.66.

6. Quigley E.M.M. Food microbiology: Prebiotics and Probiotics in Digestive Health. Clin Gastroenterol Hepatol 2019, 17, 333-344, https://doi.org/10.1016/j.cgh.2018.09.028.

7. Anal, A. K.; Singh, H. Recent advances in microencapsulation of probiotics for industrial applications and targeted delivery. Trends Food Sci Technol 2007, 18, 240-251, https://doi.org/10.1016/j.tifs.2007.01.004.

8. Min, M.; Bunt, C.R.; Mason, S.L.; Hussain, M.A. Non-dairy probiotic food products: An emerging group of functional foods. Crit Rev Food Sci Nutr 2019, 59, 2626-2641, https://doi.org/10.1080/10408398.2018.1462760.

9. Wu, J.; Zhang, J.; Chen, J.; Han, Y. Probiotics decrease the stress response and intestinal permeability of term neonates with low Apgar scores. Exper Ther Med 2019, 18, 4322-4328, https://doi.org/10.3892/etm.2019.8107.

10. Dinkçi, N.; Akdeniz, V.; Akalin, A.S. Survival of probiotics in functional foods during shelf life. Food Qual Shelf Life 2019, 201-233, https://doi.org/10.1016/B978-0-12-817190-5.00006-9.

11. Terpou, A.; Aikaterini Papadaki, A.; Lappa, I.K.; Vasiliki Kachrimanidou, V.; Loulouda A. Bosnea, L.A.; Kopsahelis, N. Probiotics in Food Systems: Significance and Emerging Strategies Towards Improved Viability and Delivery of Enhanced Beneficial Value. Nutrients 2019, 11, https://doi.org/10.3390/nu11071591.

12. Homayouni, A.; Javadi, M.; Ansari, F.; Pourjafar, H.; Maryam Jafarzadeh, M.; Ali Barzegar, A. Advanced Methods in Ice Cream Analysis: a Review. Food Anal Methods 2018, 11, 3224-3234, https://doi.org/10.1007/s12161-018-1292-0. 
13. Pourjafar, H.; Noori, N.; Gandomi, H.; Akhondzadeh Basti, A. Study of protective role of double coated beads of calcium alginate-chitosan-eudragit s100 nanoparticles achieved from microencapsulation of Lactobacillus acidophilus as a predominant flora of human and animals gut. $J$ Vet Res 2016, 71, 311-320.

14. Pourjafar, H.; Noori, N.; Gandomi, H.; Basti, A.A.; Ansari, F. Viability of microencapsulated and nonmicroencapsulated Lactobacilli in a commercial beverage. Biotech Rep 2020, 25, https://doi.org/10.1016/j.btre.2020.e00432.

15. Călinoiu, L.F.; Bianca Eugenia Ştefănescu, B.E.; Pop, I.D.; Muntean, L.; Vodnar, D.C. Chitosan Coating Applications in Probiotic Microencapsulation. Coatings 2019, 9, https://doi.org/10.3390/coatings9030194.

16. Hugues-Ayala A.M.; Andre-i Sarabia-Sainz, J.; González-Rios, H.; Vázquez-Moreno, L.; Ramos-Clamont Montfort, G. Airbrush encapsulation of Lactobacillus rhamnosus GG in dry microbeads of alginate coated with regular buttermilk proteins. LWT-Food Sci Technol 2020, 117, https://doi.org/10.1016/j.lwt.2019.108639.

17. Yin, J.; Xiang, C.; Song, X. Nanoencapsulation of psoralidin via chitosan and Eudragit S100 for enhancement of oral bioavailability. Int J Pharm 2016, 510, 203-209, https://doi.org/10.1016/j.ijpharm.2016.05.007.

18. Pourjafar, H. Probiotic cheese process deploying probiotics microencapsulation technology. IR. Patent 2010, 63525, inventory record.

19. Hilbig, J.; Hartlieb, K.; Gibis, M.; Herrmann, K.; Weiss, J. Rheological and mechanical properties of alginate gels and films containing different chelators. Food Hydrocoll 2020, 101, https://doi.org/10.1016/j.foodhyd.2019.105487.

20. Mirzaei, H.; Pourjafar, H.; Homayouni Rad, A. The effect of microencapsulation with calcium alginate and resistant starch on the Lactobacillus acidophilus (La5) survival rate in simulated gastrointestinal juice conditions. J Vet Res 2011, 66, 337-377.

21. Badhana, S.; Garud, N.; Garud, A. Colon specific drug delivery of mesalamine using eudragit S100-coated chitosan microspheres for the treatment of ulcerative colitis. Int Curr Pharm J 2013, 2, 42-48, https://doi.org/10.3329/ICPJ.V2I3.13577.

22. Hu, D.; Liu, L.; Chen, W.; Li, S.; Zhao, Y. A novel preparation method for 5-aminosalicylic acid loaded Eudragit S100 nanoparticles. Int J Mol Sci 2012, 13, 6454-6468, https://doi.org/10.3390/ijms13056454.

23. Mohanta, S.; Singh, S.K.; Kumar, B.; Gulati, M.; Kumar, R.; Yadav, A.K.; Wadhwa, S.; Jyoti, J.; Som, S.; Dua, K.; Pandey, N.K. Efficacy of co-administration of modified apple polysaccharide and probiotics in guar gum-Eudragit S100 based mesalamine mini tablets: A novel approach in treating ulcerative colitis. Int J Biol Macromol 2019, 126, 427-435, https://doi.org/10.1016/j.ijbiomac.2018.12.154.

24. Bukhovets, A.V.; Fotaki, N.; Khutoryanskiy, V.V.; Moustafine, R.I. Interpolymer Complexes of Eudragit ${ }^{\circledR}$ Copolymers as Novel Carriers for Colon-Specific Drug Delivery. Polymers 2020, 12, https://doi.org/10.3390/polym12071459.

25. Yoo, J.-W.; Giri, N.; Lee, C.H. pH-sensitive Eudragit nanoparticles for mucosal drug delivery. Int J Pharm 2011, 403, 262-267, https://doi.org/10.1016/j.ijpharm.2010.10.032.

26. Kotla, N.G.; Burke, O.; Pandit, A.; Rochev, Y. An Orally Administrated Hyaluronan Functionalized Polymeric Hybrid Nanoparticle System for Colon-Specific Drug Delivery. Nanomaterials 2019, 9 , https://doi.org/10.3390/nano9091246.

27. Patel, N.V.; Sheth, N.R.; Mohddesi, B. Formulation and Evaluation of Genistein-A Novel Isoflavone Loaded Chitosan and Eudragit@ Nanoparticles for Cancer Therapy. Materials Today: Proceedings 2015, 2 , 4477-4482, https://doi.org/10.1016/j.matpr.2015.10.055.

28. Pandey, S.; Swamy, S.; Ulla, U.; Gupta, A.; Patel, H.; Yadav, J. Cell Line and Augument Cellular Uptake Study of statistically optimized sustained release capecitabine loaded Eudragit S100/PLGA (poly (lactic-coglycolic acid)) Nanoparticles for colon targeting. Curr Drug Del 2016, 14, 887-899, https://doi.org/10.2174/1567201813666160817150621.

29. Younis, N.; Shaheen, M.A.; Abdallah, M.H. Silymarin-loaded Eudragit ${ }^{2}$ RS100 nanoparticles improved the ability of silymarin to resolve hepatic fibrosis in bile duct ligated rats. Biomed Pharm 2016, 81, 93-103, https://doi.org/10.1016/j.biopha.2016.03.042.

30. Kar, T.; Misra, A. Therapeutic properties of whey used as fermented drink. Revista de Microbiologia 1999, 30, 163-169, https://doi.org/10.1590/S0001-37141999000200015.

31. Ansari, F.; Pourjafar, H.; Jodat, V.; Sahebi, J.; Ataei, A. Effect of Eudragit S100 nanoparticles and alginate chitosan encapsulation on the viability of Lactobacillus acidophilus and Lactobacillus rhamnosus. $A M B$ Express 2017, 7, 144, https://doi.org/10.1186/s13568-017-0442-x.

32. Pourjafar, H.; Noori, N.; Gandomi, H.; Basti, A.A.; Ansari, F. Stability and efficiency of double-coated beads containing lactobacillus acidophilus obtained from the calcium alginate-chitosan and Eudragit S100 nanoparticles microencapsulation. Int J Probiotics Prebiotics 2018, 13, 77-84.

33. Homayouni, A.; Azizi, A.; Ehsani, M.; Yarmand, M.; Razavi, S. Effect of microencapsulation and resistant starch on the probiotic survival and sensory properties of synbiotic ice cream. Food Chem 2008, 111, 50-55, https://doi.org/10.1016/j.foodchem.2008.03.036.

34. Pourjafar, H. Invent Related to Multi Nozzle Extrusion Microencapsulator Device, in order to Probiotic Microorganism Microencapsulation IR. Patent 2011, 68678 , inventory record. 
35. Abdolhosseinzadeh, E.; Dehnad, A. R.; Pourjafar, H.; Homayouni, A.; Ansari, F. The production of probiotic Scallion Yogurt: Viability of Lactobacillus acidophilus freely and microencapsulated in the product. Carpath J Food Scie Technol 2018, 10, 72-80.

36. Soares, M.; Martinez, R.C.R.; Pereira, E.P.R.; Balthazar, C.F.; Cruzb, A.G.; Ranadheera, C.S.; Anderson, Sant'Ana, A.S. The resistance of Bacillus, Bifidobacterium, and Lactobacillus strains with claimed probiotic properties in different food matrices exposed to simulated gastrointestinal tract conditions. Food Res Int 2019, 125, https://doi.org/10.1016/j.foodres.2019.108542.

37. Shah, N. Probiotic bacteria: selective enumeration and survival in dairy foods. J Dairy Sci 2000, 83, 894907, https://doi.org/10.3168/jds.S0022-0302(00)74953-8.

38. Samedi, L.; Charles, A.L. Viability of 4 Probiotic Bacteria Microencapsulated with Arrowroot Starch in the Simulated Gastrointestinal Tract (GIT) and Yoghurt. Foods 2019, 8, https://doi.org/10.3390/foods8050175.

39. Shima, M.; Morita, Y.; Yamashita, M.; Adachi, S. Protection of Lactobacillus acidophilus from the low $\mathrm{pH}$ of a model gastric juice by incorporation in a W/O/W emulsion. Food Hydrocoll 2006, 20, 1164-1169, https://doi.org/10.1016/j.foodhyd.2006.01.001.

40. Ghasemnezhad, R.; Razavilar, V.; Pourjafar, H.; Khosravi-Darani, K.; Ala, K. The viability of free and encapsulated lactobacillus casei and bifidobacterium animalis in chocolate milk, and evaluation of its $\mathrm{pH}$ changes and sensory properties during storage. Ann Res Rev Biol 2017, 21, 1-8.

41. Boeris, V.; Romanini, D.; Farruggia, B.; Picó, G. Interaction and complex formation between catalase and cationic polyelectrolytes: Chitosan and Eudragit E100. Int J Biol Macromol 2009, 45, 103-108, https://doi.org/10.1016/j.ijbiomac.2009.04.009.

42. Quan, J.-S.; Jiang, H.-L.; Kim, E.-M.; Jeong, H.-J.; Choi, Y.-J.; Guo, D.-D.; Yoo, M.-K.; Lee, H.-G.; Cho, C.-S. pH-sensitive and mucoadhesive thiolated Eudragit-coated chitosan microspheres. Int J Pharm 2008, 359, 205-210, https://doi.org/10.1016/j.ijpharm.2008.04.003.

43. Barzegari, A.; Eslami, S.; Ghabeli, E.; Omidi, Y. Imposition of encapsulated non-indigenous probiotics into intestine may disturb human core microbiome. Front Microbiol 2014, 5, https://doi.org/10.3389/fmicb.2014.00393. 